\title{
ROLE OF MASS MEDIA IN AGRICULTURAL PRODUCTIVITY IN ADAMAWA STATE, NIGERIA
}

\author{
A. A. NDAGHU AND *V. B. TARU
}

(Received 12 September 2011; Revision Accepted 27 February 2012)

\begin{abstract}
The study examined the role of mass media in agriculture in Adamawa State. Specifically, it focused on the extent to which mass media have been used to communicate agricultural information dissemination, farmers' media preference, challenges experienced in accessing information through the media and the need to establish community based media. A multistage random sampling technique was adopted in selecting respondents for the study. This involved the random selection of one extension block each, from the four Agricultural Development Programme (ADP) extension zones in the state viz: Gombi, Guyuk, Mayo-belwa and Mubi. Two agricultural extension cells were then selected from each of the extension blocks and 10 farmers in each cell were randomly selected. In all 240 farmers were selected for the study. An interview schedule was used to solicit for data from the respondents. Results indicate that, majority of the farmers (69.17\%) affirmed radio as the only means through which they access production information. Also, $50 \%$ of the respondents preferred television to other media available for communicating agricultural information. All the variables related to the challenges experienced by farmers in accessing information through the mass media and the perception of the community based media were significant at $5 \%$ level, attesting a strong relationship. Pest and disease control had $41.7 \%$, improved crop varieties had $25 \%$ and weed control had $16 \%$, these were prominent amongst agricultural information disseminated through mass media to farmers. The study suggested the establishment of a community based television stations targeted on agricultural programmes to farmer as this will go a long way in improving not only the quality of information but also its access.
\end{abstract}

KEY WORDS: Extension, Productivity, Access, Information

\section{INTRODUCTION}

Experience has shown that, there are no cases of successful development of a major country in which the rise in agricultural productivity did not precede or accompany such development (Abubakar, et.al., 2009). Reports have also shown that, successes of agricultural development programmes in most developing countries largely depend on the nature and extent of use of mass media in mobilization of people for development. Planners in developing countries as well realize that, the development of agriculture could be hastened with effective use of mass media (Purushothaman, et. al., 2010). According to Ajayi (2003) and Ani (2007), mass media are channels of communication which can expose large number of people to the same information at the same time within a short space of time. Mass media include technologies through which information is passed to users as sound, sound and moving pictures or in the form of print. Extension service organizations use mass media because of the high speed and low cost with which information can be communicated over a wide area. The mass media are generally useful as sources of initial information to farmers and veritable tools conveying production information to farmers on new developments and emergencies.
Effective communication of new research findings and technologies in agriculture to rural farmers remain a promising strategy for increasing agricultural productivity (Banmeke and Olowu, 2005). In general, production information that are usually conveyed through the mass media may include techniques of applying fertilizers, insecticides and fungicides to crops, improved methods of crop cultivation, and soil conservation techniques, harvesting technology and storage of crops (Ani, 2007; Egbule and Njoku, 2010). There are also new technologies of animal husbandry as well as processing and marketing various agricultural products for the farmers to adopt innovations and put them to use, such innovations ought to reach the farmers and or their homes through effective extension and mass media channels (Egbule and Njoku, 2010).

The mass media are increasingly becoming veritable instruments for transforming agriculture. On Nigerian agricultural landscape, the major media systems that have a lot to contribute are radio, Television and the print media (Ogunbameru, 2001; Alabi, 2010). Available information shows that Nigeria has well developed and virile broadcasting system when compared with other developing countries. However, the great potentials of these media for farmers in agriculture

A. A. Ndaghu, Department of Agricultural Economics and Extension, Moddibo Adama University of Technology P.M.B. 2076 Yola, Adamawa State, Nigeria.

*v. B. Taru, Department of Agricultural Technology Federal Polytechnic P.M.B. 35 Mubi, Adamawa State, Nigeria. 
is yet to be fully exploited for reasons ranging from high cost of transmission to the absence of proper framework within which to integrate the media into the agricultural development agenda. However, the media system in Nigeria are highly centralized and clustered in urban areas. Consequently, very little of the needed information reach the rural communities, where most of the population live and where the actual farming is taking place.

There is also the problem of widespread nonliterate farmers, most of whom cannot read and understand the information at their disposal, the high cost of newspapers, radio and television limits the use of these channels by many present and prospective farmers. Also, the editors and programme directors are more interested in producing programmes that are of high commercial value there by gate keeping most agricultural information. As a result, only few agricultural programmes are presented in these media, most often, these information are not properly scheduled to suit the farmers and their information need. Consequently, most farmers are constrained to rely on third parties for agricultural information, very often, the third parties are biased and may have vested interest as they disseminate information. It is against this background that the study analyses the role of mass media in agricultural productivity in Adamawa State, Nigeria and specifically:

$>$ Determined the socio-economic characteristics of the respondents in the study area

$>$ Investigated the mass media through which respondents access agricultural information

$>$ Assessed the agricultural information that disseminated through the mass media

$>$ Assessed respondents' mass media preferences for sourcing agricultural information and

$>$ Determine respondents' perception towards having a community based media station

\section{METHODOLOGY}

The study was carried out in Adamawa State of Nigeria between March and May 2010. Adamawa state lies between latitude $7^{\circ} 28^{\prime} \mathrm{N}$ and $10^{\circ} 55^{\prime} \mathrm{N}$ of the Equator and Longitude $11^{\circ} 30^{\prime} \mathrm{E}$ and $13^{\circ} 45^{\prime} \mathrm{E}$ of the Greenwich Meridian, with a population of $3,168,101$, in the National Population Census of 2006 (Federal Republic of Nigeria Official Gazette, 2007). Adamawa State is bounded in the north by Borno State, to the east by the Republic of Cameroon, in the south by Taraba and in the west by Gombe and Borno states. Agriculture offers the source of livelihood to majority of the population through subsistence traditional farming. According to Sajo and Kadams (1999), the major crops grown in the areas include millet (Eluesine coracana), groundnut (Arachis hypogea), Maize (Zea mays), sorghum (Sorghum bicolor), rice (Oryza sativa), Yam (Dioscorea spp), cowpea (Vigna unguiculata), soyabeans (Glycine max), beniseed/sesame (Sesamum indicum), cassava (Manihot esculenta), cotton (Gossypium spp) and sweet potato (Ipomea batatas), vegetables like carrots (Dacus carota), Tomatoes (Lycopersicon lycopersicum), spinach (Amaranthus spp), garden egg (Solanum melongena), onion (Allium cepa), sorell/roselle (Hibiscus sabdariffa), and okra (Abelmoschus esculentum) among other crops are also grown intensively in the area during the dry season. In addition to crop farming, some farmers keep livestock such as cattle, sheep, goat, pigs and poultry.

A multistage random sampling technique was adopted in selecting respondents for the study. This involved the random selection of one extension block each, from the four Agricultural Development Programme (ADP) extension zones in the state viz: Gombi, Guyuk, Mayo-belwa and Mubi. Two agricultural extension cells were then selected from each of the extension blocks where Garkida \& Gabun, Waduku \& Chikla, Jereng \& Mbanba \& Muchalla were selected from Gombi, Guyuk, Mayobelwa and Mubi zones respectively. Ten percent of the farmers in each of the eight agricultural extension cells selected were randomly sampled for the study. This selection was based on the list of farmers within the extension cells obtained from the various Village Extension Agents (VEAs) in the area. In all, 240 respondents were involved in the study.

Data for the study was obtained using a validated and pre-tested structured interview schedule administered to the respondents: on socio-economic characteristics, mass media through which they access agricultural information. Type of agricultural information sought through the mass media, respondents mass media preferences, challenges experienced and perception towards having community based media stations. Data obtained were subjected to descriptive statistics such as frequency count, percentage and mean.

\section{RESULTS AND DISCUSSION}

Table 1 indicates that majority of the respondents $(68.33 \%)$ were males. This result corroborates Ndaghu et al. (2009), who found that most farm families in the study area are headed males and are responsible for most production decisions. The few of the respondents that are females are either widows who are household heads in their own right or married women whose husbands are not on ground as at the time of the survey and participated in the research as de facto household heads.

Table 1 also, revealed that, $67.50 \%$ of the respondents were married .In both urban and rural parts of the study area, marriage is a respected institution .It bestows on people social status, recognition and make the individuals to be considered responsible in the community (Akinbile, 2007). Also, Ndaghu et al. (2009) revealed that most farmers in the study area were married. As married individuals, such respondents may not be responsible for the upkeep and welfare of themselves alone but also of other members of the family, this therefore beholds it on them to take advantage of any productivity enhancing opportunity like the use of mass media to source and access information on improved agricultural practices. Table 1 indicates that $38.83 \%$ of the respondents had no formal education; while, $15.83 \%, 25.83 \%$ and $20 \%$ attained primary, secondary and tertiary levels of education respectively. The high proportion of the respondents with no formal 
education poses serious challenges for development and effective use of the mass media and subsequent adoption of productivity enhancing innovations in the study area. According to Yomi-Alfred (2006), farmers with higher level of education are more likely to access and adopt higher number of innovations than those with no or less education. Table 1 further revealed that, mean years of farming experience was $16 \pm 6$ years. This shows that the respondents have relatively good farming experience. In a related study, Tizhe (2008) found that, Years of farming experience greatly influence farmers output/productivity.

Table 1: Socio-economic Characteristics of the Farmers

\begin{tabular}{lll}
\hline Sex & Frequency & Percentage \\
\hline Male & 164 & 68.33 \\
\hline Female & 76 & 31.67 \\
\hline Total & 240 & 100 \\
\hline Marital Status & & \\
Single & 56 & 23.33 \\
\hline Married & 162 & 67.50 \\
\hline Windows & 22 & 9.17 \\
\hline Total & 240 & 100 \\
\hline Educational level & & \\
Non & 92 & 38.33 \\
\hline Primary & 38 & 15.83 \\
Secondary & 62 & 25.83 \\
\hline Tertiary & 48 & 20.00 \\
\hline & & \\
Years of Farming & & 35.83 \\
$\mathbf{1 - 1 0}$ & 86 & 41.67 \\
$\mathbf{1 1 - 2 0}$ & 100 & 22.50 \\
$\mathbf{2 1 - 3 0}$ & 54 & 100 \\
\hline Total & 240 & \\
\hline
\end{tabular}

Table 2 revealed that majority of the respondents $(69.17 \%)$ indicated radio as the main mass media through which they source and access agricultural information, while only $20 \%$ and $17 \%$ of them sourced and accessed agricultural production information from Television and Newspapers respectively. This finding corroborates several studies (Olowu and and Igodan, 1989; Mohammed and Wonasa, 1993, Yahaya, 1995; and Olowu et al., 2004), which give credence to radio as a major source of information in Nigeria. According to Ifejika et al. (2007), the importance of radio to rural farmers is attributed to its merits such as affordability, low cost of maintenance, ease of operation, wider reach, availability and localization of programmes. It is in this light that, Ogunbameru (2001), opined that, due to high cost of access and the technicalities involved in use of Television, the most reliable and dependable mass media is radio; radio cost less and can easily be operated even by the non-literate farmers who constitute majority of the farming populace.

Table 3 shows the nature of agricultural information respondents sourced and accessed through the mass media. The table indicates that, information on pests and diseases control (41\%), improved crop varieties $(25 \%)$ and weeds control (16.67\%) were the most sought through the mass media. This result indicates that the farmers had access to and sourced agricultural information most on crop pests and diseases followed by information on improved crop variety and then information on weed control. Therefore, agricultural extension organizations and agents working within the study area should focus in mind that farmers mostly access and sourced agricultural information in the areas of crop pests and diseases control, improved crop varieties and weed control in that order to improve agricultural productivity. 
Table 2: Mass Media through which Respondents Sourced and Accessed Agricultural Information

\begin{tabular}{llll}
\hline Mass Media & Frequency $^{*}$ & Percentage & Remark \\
\hline Radio & 166 & 69.17 & High \\
Television & 40 & 16.17 & Low \\
Newspaper & 34 & 14.17 & Low \\
\hline
\end{tabular}

Source: Fields Survey 2011

- These are multiple responses

Table 3: Agricultural Information Respondents Sourced and Accessed through the Mass Media

\begin{tabular}{llll}
\hline Variables & Frequency $^{*}$ & Percentage & Rank \\
\hline Improved crop variety & 60 & 25 & 2 \\
Fertilizer Application & 12 & 5 & 7 \\
Processing and storage & 20 & 8.33 & 5 \\
\hline Tractor Hiring & 20 & 8.33 & 5 \\
Pest and disease control & 100 & 41.7 & 1 \\
Erosion Control & 10 & 4.17 & 9 \\
Weed Control & 40 & 16.67 & 3 \\
\hline Marketing of Produce & 12 & 5 & 7 \\
\hline Improved Planting Techniques & 30 & 12.5 & 4 \\
\hline Livestock Management & 18 & 7.5 & \\
\hline
\end{tabular}

Source: Field Survey 2011

- These are multiple responses

Table 4 indicates respondents' mass media preferences. It revealed that, $50 \%$ preferred television, $34.2 \%$ preferred radio while $15.8 \%$ preferred newspaper. This result shows that despite radio being the main medium through which the respondents sourced and accessed information to improve agricultural productivity, television is the respondents' most preferred medium for sourcing and accessing agricultural information. The preference for television among most of respondents may be for the fact that television appeals to both senses of sight and hearing. In the opinion of FAO (1998), television is a highly persuasive and effective communication medium that has become a tool to increase awareness about specific development problems and stimulate local discussion and possible solution. According to Olowu (1991), television has the potential of increasing farmers' knowledge in the $21^{\text {st }}$ century Nigeria. The problems of television are cost of the hardware, cost of maintenance and inadequate source of power for television in most rural areas, thereby restricting television usage to the urban areas. This is the crux of the matter, in spite of the respondents' preference for television, it is through radio that most of them sourced and accessed information for agricultural production due to high cost and limited or non-availability of television signals in most rural areas. This finding is a case of the available not necessarily being the desirable.

Table 4: Respondents' Mass media Preferences

\begin{tabular}{lll}
\hline Mass media & Frequency & Percentage \\
\hline Radio & 82 & 34.17 \\
Television & 120 & 50.00 \\
Newspaper & 38 & 15.83 \\
Total & 240 & 100 \\
\hline
\end{tabular}

Source: Field survey 2011

Table 5 indicates that, there is a significant relationship between farmers' age, sex, and educational level and their need of community based mass media, the young, male and educated farmers believe that there is the need for a community based mass media particularly television which the farmers can rely on and can make contact as at when due. Table 6 indicates that power failure, lack of signals and high cost of television gadgets and maintenance are the major challenges experienced by farmers in sourcing and accessing agricultural production information from the mass media. 
Table 5: Respondents' challenges in Sourcing and Accessing Agricultural Information through the Mass Media

\begin{tabular}{|c|c|c|c|}
\hline Variables & DF & $x^{2}$ & Decision \\
\hline Power*benefit & 3 & 1.9495 & Significant \\
\hline Power*concept & 3 & 3.5654 & Significant \\
\hline Power*source & 3 & 0.5078 & Significant \\
\hline Networkbenefit & 6 & 2.8437 & Significant \\
\hline Network*concept & 4 & 6.5714 & Significant \\
\hline Network*source & 6 & 11.9855 & Significant \\
\hline Cost*benefit & 9 & 11.0898 & Significant \\
\hline Cost ${ }^{\star}$ concept & 6 & 18.4345 & Significant \\
\hline Cost*source & 9 & 11.8291 & Significant \\
\hline
\end{tabular}

Source: Field survey 2011

- represent against

Table 6: Relationship between Respondents' Socio-economic characteristics and their Perception of the need for Community Based Mass Media

\begin{tabular}{llll}
\hline Variables & DF & $\mathbf{X}^{2}$ & Decision \\
\hline Sex & 3 & 3.5859 & Significant \\
Age & 3 & 3.6187 & Significant \\
Education & 9 & 6.1142 & Significant \\
\hline
\end{tabular}

Source: Field survey 2011

\section{CONCLUSION}

The study evaluated the role of mass media in agricultural productivity in Adamawa state, Nigeria with an effort to examine the extent to which mass media have communicated agricultural information to rural farmers, to assess the nature of agricultural information dissemination, preference of farmers to available media, problems faced by farmers in accessing media and the need to establish a community based media. Given farmers preference for television over other kind mass media channels, there is need to establish a community/rural television stations which should feature special agricultural programmes targeted at rural farmers.

\section{REFERENCES}

Abubakar, B. Z., Ango, A. K and Buhari, U., 2009. The Roles of Mass Media in Disseminating Information to Farmers in Birnin Kebbi Local Government Area of Kebbi State: A case study of state Fadama 11 Development Project. Journal of Agricultural Extension 13(2): 42-54.

Ajayi, M. T., 2003. Analysis of Mass Media Use for Agricultural Information by farmers in Egbeda Local government of Oyo State, Nigeria Journal of Extension Systems 19(2);45-55.

Akinbile, L. A., 2007. Socio-Economic and Health Related Constraints of Oil Palm Processors in Osun State, Nigeria. The Nigerian Journal of Rural Extension and Development 2:1-8
Alabi, E. J., 2010. Farmers' Perception of Mass Media as Channels of Extension Service Delivery; A Case study of Yola North and south Local Government Areas of Adamawa State. Unpublished B. Tech Project, Federal University of Technology Yola.

Ani, A. O., 2007. Agricultural Extension: A Pathway for Sustainable Agricultural Development. Apani publishers Kaduna. PP. 15-28.

Banmeke, T. O and Oluwu, T. A., 2005. Accessibility of Women Farmers to Agricultural Information in South Western Nigeria. South Africa Journal of Agricultural Extension (34)2: 237-243

Egbule, P. E and Njoku, E. M., 2010. Mass Media Support for Adult Education in Agriculture in Sourthern Nigeria. Retrieved: http://.iizdvv.de/index.php?article_id=4838\&clang= 26/7/2011

Federal Republic of Nigeria FRN., 2007. Official Gazette, Lagos, May 15

Food and Agriculture Organization FAO., 1998. Knowledge and Information for Food Security in Africa, from Traditional Media to the Internet FAO Research, Extension and Training Division, Communication for Development Group. Extension Education Communication Services (SDRE). Pp 22-3- 
Ifejika, P. I., J. O. Ayanda, G. O. Nwabeze., 2007. Content Analysis of Radio Niger Progamme on Production of Fisheries around Kainji Lake Basin, Nigeria. Nigerian Journal of Agricultural Extension 12, (10): 50-58

Mohammed, I., T. J. Wanaso., 1993. Analysis of Sources of Farm Information of Farmers, Western zone, Plateau ADP, In Olowu T.A. (ed). Nigerian Journal of Rural Extension and Development 1(1\&3):49-55

Ndaghu, A. A., D. C. Maurice, and E. Zubairu., 2009. Adoption of the New Rice for Africa (NERICA) Rice Variety Among Small Scale Farmers in Taraba State. Nigerian Journal of Tropical Agriculture 11:259-265

Ogunbameru, B. O., 2001. Practical Agricultural Communication. Daily Graphics Ibadan. PP. 79103.

Olowu, T. A., 1991. The Effect of Television Farm Progamme on Farmers Knowledge on Improved Farm Practices in Oyo State. In T.A. Oluwo and J. A. Akinwumi (eds). Proceedings of the National Coference of the Ibadan Socioeconomic Group on Development Strategies in the $21^{\text {st }}$ Centuary Nigeria July $7-8^{\text {th }} 151-156$
Olowu, T. A., C. A. Ayanwu, and P. Obinne., 2004. Farm Radio Network: A Baseline Survey of Six States of Nigeria. A Report Submitted to the Food and Agriculture Organization (FAO) of the United Nations, December 7

Purushothaman, C., Kavaskar, M., Reddy, Y. A. and Kanagasabapathi, K., 2010. Role of Mass Media in Agriculture. Retrieved:

http://docs.google.com/viewer?a=v\&q=cache!nX mlzKKU5 8j:agropedia.iitk.ac.in/openac $26 / 7 / 2011$

Sajo, A. A., and A. M. Kadams., 1999. Food and Cash Crops. In A. A. and A.L (eds) Adamawa State in Maps. Paraclete Publishers, Yola Nigeria. 61-72

Yahaya M. K., 1995. Determination of Agricultural Information Needs and Media Use Pattern of Women Farmers in North-Central Nigeria, Unpublished Ph.D Thesis, University of Ibadan, Ibadan Nigeria.

Yomi-Alfred., 2006. Adoption of Improved Varieties of Cassava Production by Farmers in Osun State. The Osun Journal of Agricultural Science 4:4048 